口特＼cjkstart集＜声の分析と臨床＞

\author{
声楽発声指導者の立場から \\ —リアルタイム呼吸運動チェックシステム（ストレインゲージ）を \\ 用いた歌唱指導について——
}

斉田 正子1,2) 斉田 晴仁,23)

\begin{abstract}
要 約: 声楽発声指導は，今日まで経験に基づいた主観的な方法で行われてきた。呼吸法の 指導は, 声楽発声指導に拈いて重要な課題であるが, 見るだけではわかりづらいため, 指導者 によっては, 胸腹部の動きを手で確認して行っていた。しかし歌唱中の動きの確認は難しく, またセクハラの問題もあり, 客観的に呼吸運動を知る方法の開発が望まれていた。 ストレイン ゲージは伸展による電気抵抗の変化で伸展度を計測できる機器で, これを胸部と腹部にベルト の一部として取り付け,リアルタイムに呼吸運動を調べるシステムを考案した。データはオシ ログラフを模したソフトで表示し, 客観的な呼吸運動の観察が可能で, 声楽発声の指導や音声 治療の発声訓練に有効であることがわかった。
\end{abstract}

索引用語：音声治療，発声訓練，ストレインゲージ，声楽，発声

\title{
Application to Vocal Music Training of Newly Developed Strain-Gage Type System for Checking Respiratory Movement in Real Time - From the Perspective of the Vocal Music Coach__
}

\author{
Masako Saida ${ }^{1,2)}$ and Haruhito Saida ${ }^{2,3)}$
}

\begin{abstract}
Until now, vocal music training has been undertaken subjectively based on the experience of experts having long experience.

Although respiratory coaching is very important for singing, understanding how the student is breathing during vocalization is quite difficult relying on visual means alone. Some voice coaches have attempted to overcome this diffculty by touching the student's abdominal and thoracic areas.

Even with this method, however, it has been difficult to gain full understanding of respiratory movement during singing. Moreover, there have been problems as to potential sexual harassment. A new coaching method enabling such understanding of respiratory movement by objective means has thus been eagerly awaited.

A strain gage measures the degree of stretching based on changes in electrical resistance according to tensile level. A new strain-gage type system was developed that analyzes
\end{abstract}

日本大学芸術学部音楽科 ${ }^{1)}:$ T 176-8525 東京都練馬区旭丘2-42-1

ヴオイステック音声研究所 ${ }^{2)}$ ，さいだ耳鼻咽喉科気管食道科クリニック ${ }^{3)} ：$ † 222-0037 横浜市港北区大倉山 3-42-16

${ }^{1)}$ Department of Music, Nihon University College of Art: 2-42-1, Asahigaoka, Nerima-ku, Tokyo 176-8525, Japan

${ }^{2)}$ Voice Tec Vacal Art Science Laboratory, ${ }^{3}$ Saida Ear, Nose Japan \& Throat Clinic: 3-42-16, Okurayama, Kouhoku-ku,

Yokohama-shi, Kanagawa 222-0037, Japan

2009 年 1 月 26 日受稿 
respiratory movement in real time using belts fixed around the abdominal and thoracic areas. Data is displayed on a computer screen in a form similar to an oscillograph, enabling objective observation of respiratory movement. The new system is seen to be highly effective for use in vocal coaching, as well as for training in conjunction with voice therapy.

Key words: vocal music, voice therapy, strain gage, respiration, voice training

\section{はじめに}

声楽の発声と歌唱の指導は, 聴覚, 視覚等に頼った 経験的な方法が主体であり客観的な判断ではないこと が多かった．歌声や歌唱は，人間の感性に頼る主観的 な芸術であるが，音楽教育上や正当な歌声の評価をす る場合などでは，物理的な音声である声を客観的に評 価する方法も必要と考える. 私たち声楽発声指導者が, 指導するにあたって，音声障害の学生に遭遇する機会 も多い，芸術としての主観的，観念的な指導だけでは なく, 音声生理学の知識を勉強して音声障害者を早く 発見し，また作り出さないような指導法の確立も重要 と考える。今回，発声法を客観的に評価する新しい方 法，ストレインゲージを用いたリアルタイム呼吸運動 チェックシステムを考案し, 発声, 歌唱指導に応用, 実施したので講演する。また，これまで研究分野で行 われてきた，音響分析，EGGとの併用について最近 の進展を踏まえ報告する。

\section{歌唱の客観的評価の試み}

歌唱の成立はたいへん複雑である。多くの知識と経 験を基に，発声源としての身体と精神を，高度なバラ ンスを保ちながら成り立つ芸術である，芸術としての 歌唱は，理屈抜きに人に感動を与えればその目的は達 せられる，しかしその感動を促すためには，個々の人 間がそれまでの経験や知識に基づき脳内で活発な情報 交換を起こしているのであり, 経験や知識はその感動 を呼び起こす大きな要素となる。歌唱の評価において は, これらの知識や経験が重要であり, 場合によりさ まざまな心理的要因が無意識のうちに正当な歌唱の評 価を阻害することもありうる。歌は，音としての声の 時間的変化であり音響学などによる音声生理的な分析 も可能であるが, これだけでは，芸術のもっている感 性に訴える部分の分析はいまだ不可能と考える。音声 科学的なアプローチは, 必要であるが, 芸術的な観点 からの分析も重要で, 芸術と科学的手法によるアプ ローチの歩み寄りにより, 理想的な芸術としての歌唱 が評価できるものと考える。
そこで, 私は現在, 芸術としてのアプローチとして， 次のような項目に分けて歌唱を分析評価している.

1.ソルフェージユ的基礎力として 1)正しい音程, 2)正しいリズム,

2. 声の評価として 1)大きさ，2)声区による音色, 3) 全体的な音色,

3. 芸術的表現力として 1) 表現力, 2)言葉の正確さ, 明瞭性，3) 音楽性,

4. その他のステージ上の要素など

以上の 4 つ要素から評価している. 声については, 大きい声であるか, 小さい声か, また高い声と低い声 が出せるか，低い声と高い声の音色の差があるかない か, レガートができるかできないか, 言葉の伝達がで きるかできないかなどが重要になる.

歌唱の評価法の試みを表 1 に示す.

以上のように，これまでより具体性のある評価法で 音楽教育に役立てたいと考えている.

\section{歌唱の客観的評価の必要性}

音声障害のなかには, 発声の悪習慣が原因といわれ ているものがあり, 歌手, 俳優, 教師など, 声の酷使 を伴う就業者に音声障害者が多いことはよく知られて いる. 声楽発声指導者も, 声楽発声に扔いて声のトラ ブルを起こした音声障害者に遭遇する機会も多い，声 楽発声に打いては, 声帯結節が非常に多く, この発症

\begin{tabular}{|c|c|c|}
\hline \multicolumn{3}{|c|}{ 1. ソルフェージュ的基礎力 } \\
\hline & 正しい音程 & 15 \\
\hline & 正しいリズム & 15 \\
\hline \multicolumn{3}{|c|}{ 2. 声の評価 } \\
\hline & 大小 & 10 \\
\hline & 声区による音色 & 10 \\
\hline & 全体的な音色 & 10 \\
\hline \multicolumn{3}{|c|}{ 3. 芸術的表現力 } \\
\hline & 表現力 & 10 \\
\hline & 言葉の正確さ, 明瞭性 & 10 \\
\hline & 音楽性 & 10 \\
\hline \multicolumn{3}{|c|}{ 4. その他 } \\
\hline & ステージマナーなど & 10 \\
\hline tot & & 100 \\
\hline
\end{tabular}


には発声法がかかわっていると考えられる11。発声や 歌唱の指導において，声带結節のようなトラブルを作 り出さないような方法が求められている.

声楽発声において, 声のトラブルを起こしやすい原 因としては,

1，指導者の意図が受講者に伝わらず，その意図と は違った方法で発声してしまう場合

2. 指導者の意図しない方法で受講者が発声してい ても指導者が気づかない場合

3．指導者自身の発声指導に何らかの問題がある場 合

4．舞台の音響や空調など発声環境に問題がある場 合

5 . 指導者以外の演出家，指揮者等の意図により発 声に無理がかかる場合

6. 本人の心身の不調による場合などが考えられる.

一方，良い発声では声带結節などのトラブルは，起 こしにくく，また良い発声で，これらの病態を改善さ せることも知られている。したがって良い声楽発声法 の研究と実践は，本学会のテーマの一つである音声治 療にも役立てられるのではないかと考える。声楽発声 指導では，呼吸法の指導が重要であることは異論がな いであろう。これまでは受講者の胸郭や腹部を直接さ わったり，指導者の呼吸法を理解させるために，胸郭 や腹部を触らせたりして，指導の理解を深めていた。 しかし歌唱中に続けて触りながら動きを調べることも 難しく，また今日セクハラの問題等で実施しづらく なってきた経緯もあり，客観的な評価ができる機器の 開発が期待されていた。

\section{ストレインゲージを用いたリアルタイム呼吸運動 チェックシステム}

声と呼吸機能のチェックとしては, これまで空気 力学的方法があり, 臨床や研究分野で使われていた が，口が器具で塞がれ実践的な歌唱指導には不向きで 歌唱に影響がないような機器が必要であった。そこで 呼吸ピックアップ（ストレインゲージ）を用い胸郭と 腹部の動きをリアルタイムに調べるシステムを考案し た ${ }^{2)}$ 。ストレインゲージは，ゲージ部分が引き伸ばさ れると電気抵抗が変わり，その変化をモニター上で表 出することができる機器で，胸郭や腹部のベルトの一 部に取り付けることにより，その動きで呼吸運動を調 ベることが可能である.

\section{1. 方法}

呼吸運動では，肺に空気が出入りするため，胸郭や

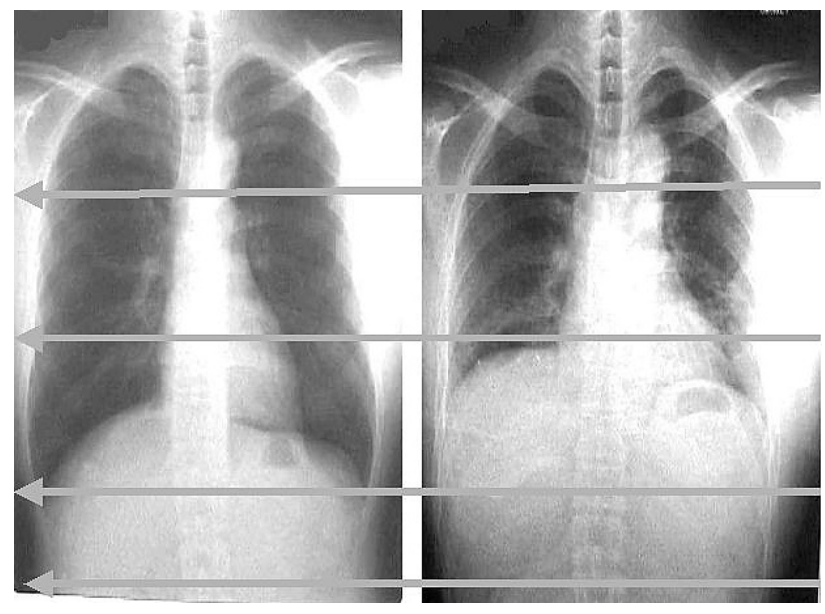

図 1 吸気時 (左), 呼気時 (右) の胸部 X 線 横線は想定されるストレインゲージ設置位置を示す

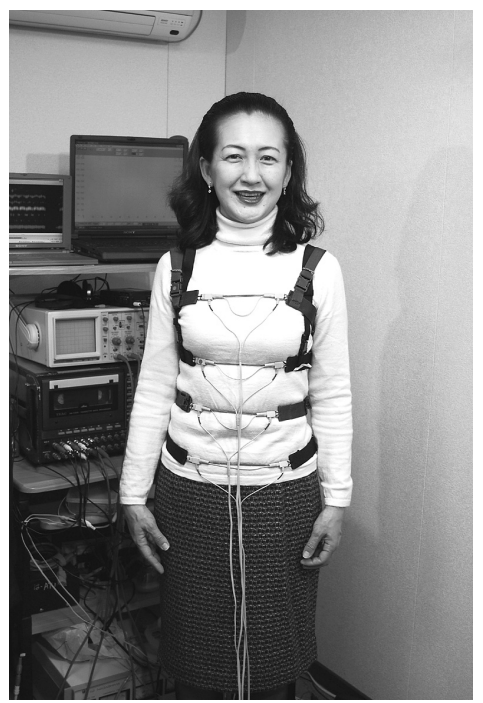

図 2 ストレインゲージの設置 上から上胸部, 下胸部, 上腹部, 下腹部とする。

腹部が大きく動く。図 1 は吸気時と呼気時の胸部 X 線である，X線で肺の位置を確認すると，声楽指導で 一般に考えられている胸部と腹部の関係とは異なるこ とがわかる。吸気時には肺下部先端は臍近くまで下降 し,これは胸骨下端と恥骨を結ぶ線の中央に位置する。 歌唱での複雑な呼吸運動を調べるために，4 本のスト レインゲージを, 図 2 のように上胸部, 下胸部，上腹 部, 下腹部に設置する。 そのデータは音声と同時にデー タレコーダに収録しデジタルオシログラフを模したソ フトで表示する。本システムでのストレインゲージは 少しの伸び縮みに対しても俊敏に反応するためリアル タイムの表出が可能である. 


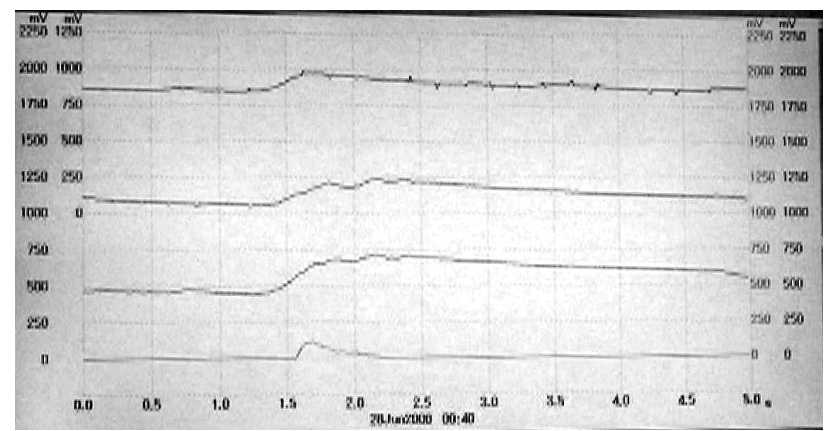

図 3 ストレインゲージでの結果（安静時呼吸）

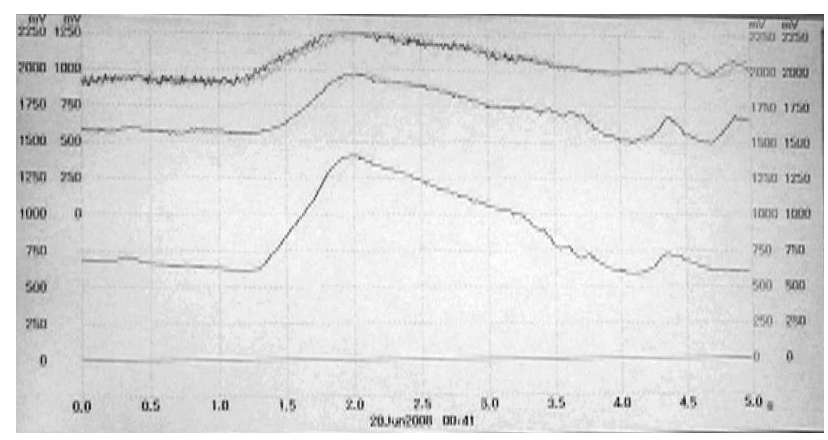

図 4 ストレインゲージでの結果（歌唱時の呼吸）

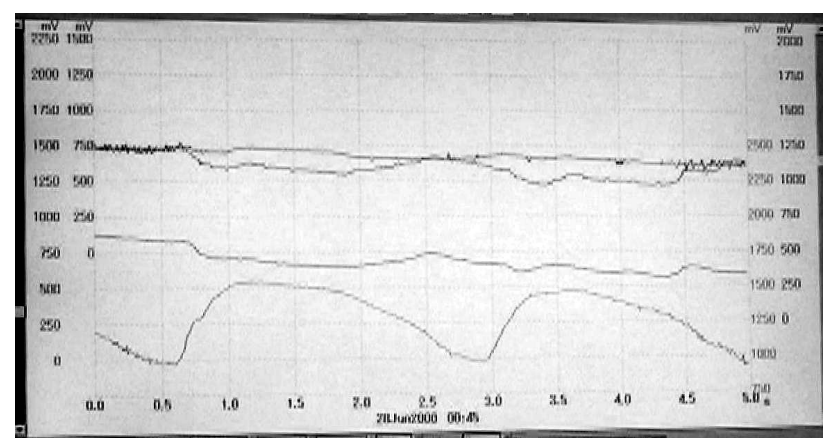

図 5 ストレインゲージでの結果

(下腹部を意図的に出す呼吸)

\section{2. ストレインゲージの表出結果パターン}

結果は相対的な動きとして表出され, 被検者の体格 により絶対的な值は異なるため, デー夕の解釈は数本 のストレインゲージの相対関係から, 判定するのが妥 当と考えている. 図 3 は, パソコンに表出された結果 でX軸は時間 $(500 \mathrm{~m} / \mathrm{sec}), Y$ 軸は, 相対的な変化幅で, ゲージが引き伸ばされると上方に向かい，縮むと下降 する。今回，私が被検者になり，基本的な分析結果を 提示する.

図 3 のように安静時呼吸では, 全体的に緩やかな上 昇が起こる。下胸部と上腹部の動きがやや大きい。歌 唱時での呼吸は, 下胸部と上腹部のゲージの動きが顕

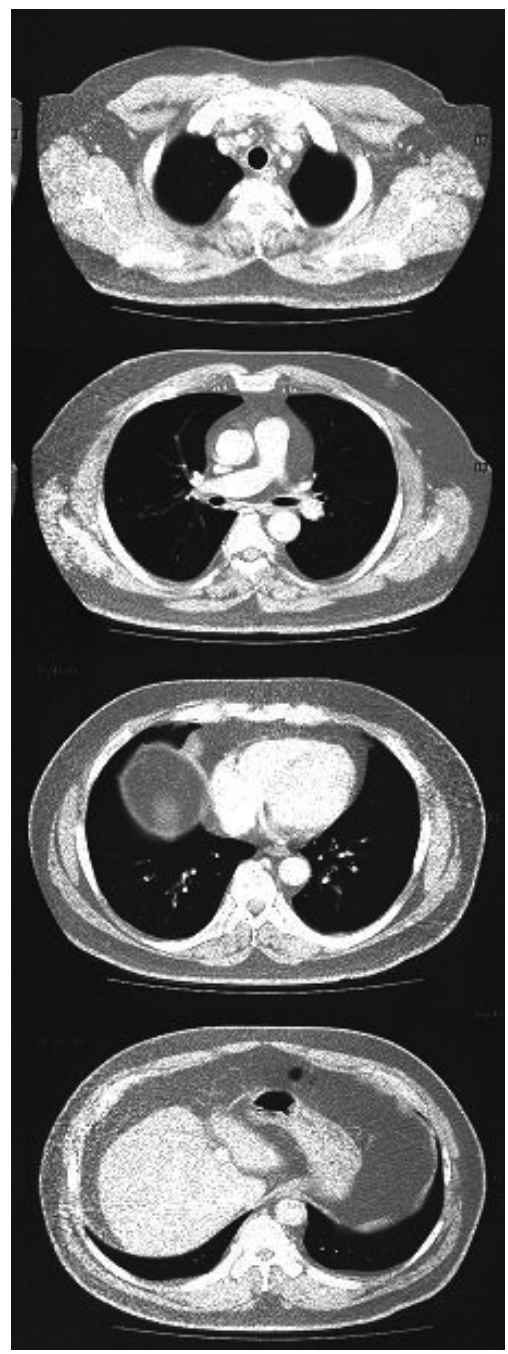

図 $6 \mathrm{CT}$ による体幹の横断面 （図1の部位に準じる）

著に増加するが，上胸部と下腹部はあまり動かないパ ターンとなった（図 4). 図 5 のように意図的に下腹 部を前に突き出すような運動を行うと, 下胸部と上腹 部は逆位相の動きのパターンとなり，上胸部ではあま り変化を示さなかった。

\section{3. 理想的な呼吸の検討}

良い発声のためには，呼吸法は伝統的にも経験的に も腹式呼吸が望ましいとされている。しかし前述した ように腹式呼吸にもいろいろなパターンがあり，下腹 部を突き出すような呼吸法は, 逆に下胸部, 上腹部が 狭くなるような動きを示すことがある。図 6 は，CT 画像で，上から頭側，下は足側に近い横断面を示して いる。図 1 の上胸部, 下胸部，上腹部は，図 6 の上か ら 2，3，4番目のような位置に該当する．各画像で上 が腹側である，黒く見える肺が，足方では背中側に回 り込んでいるのがわかる。図 7 は CT 画像による体幹 

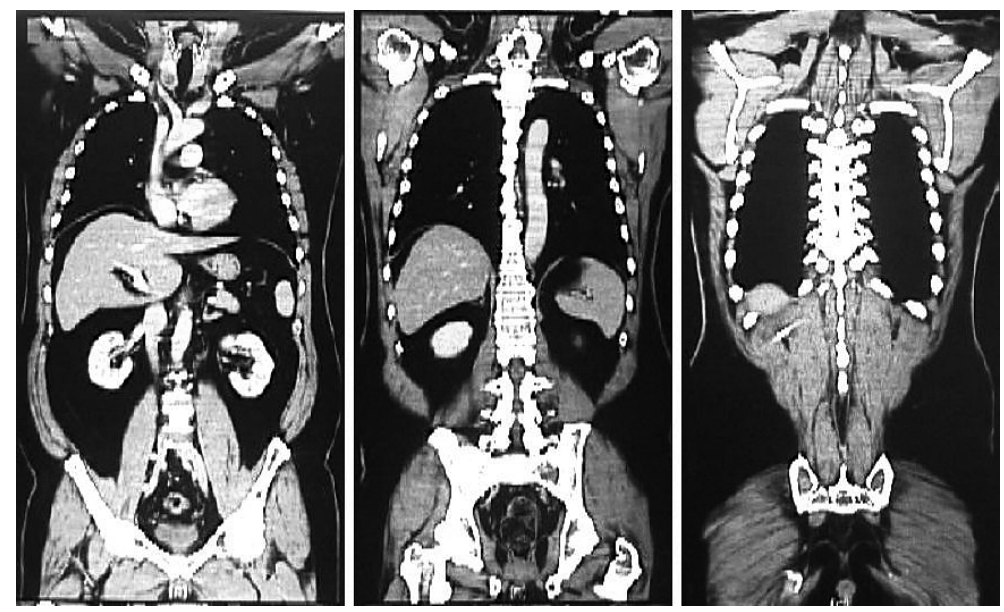

図 7 CTによる体幹の前額断（左から腹側，右は背中側）

の前額断像で，腹側は心臓などが占め，肝臓により横 隔膜が上がっているため肺の占める割合は少ない，し かし背中側では，黒く見える肺が大きく拡がっている のがわかる、私の歌唱時の呼吸では，ストレインゲー ジは，下胸部と上腹部の動きが大きかった。これは， CTでも示されたように，肺を大きく拡張させ吸気を 多く取り达むためのものである。一般に提唱されてい る腹式呼吸とは，下胸部，上腹部を拡げて行う呼吸法 と考えることができ, 胸腹式呼吸法といってよいと考 える，腹式呼吸を指導する場合，単に腹を突き出す呼 吸法では，胸郭が狭くなり吸気が不十分になってしま うので，同時に胸を張り胸郭が狭くならないようなア ドバイスも必要かと思われる。さらに芸術歌唱を行う 声楽訓練においては，下胸部から上腹部を拡げ胸郭を 拡げて，十分吸気を行いながら，腹囲を拡げることに より, 腹部臓器の下降を行い, 横隔膜を下げる呼吸法 を指導すべきだと考える。また CT で明らかなように 肺が背中側に大きく拡がっているので，背中側の胸郭 を拡げるような呼吸, 下胸郭の拡張を行う呼吸法を指 導するのも肝要だと考える。

初心者では，息を吸わせると胸を高く上げてしまう 場合がある。これは，ストレインゲージでは上胸部の 拡張と表される。この場合，胸骨，鎖骨が上がってし まい，それに付着する外喉頭筋も上方に移動し内腔を 圧迫し, 結果的に咽頭腔が狭くなり共鳴腔の狭小化を 引き起こすので望ましくない，胸を上に上げるだけで は，胸郭は十分に拡がらず，横隔膜の下降も起きにく い。また胸郭を拡げないで下腹を突き出すと，胸郭が 狭まってしまう場合があるので注意が必要である。こ れらは，ストレインゲージの使用で，客観的に判断す ることが可能である。歌唱での呼吸法に関して重要な

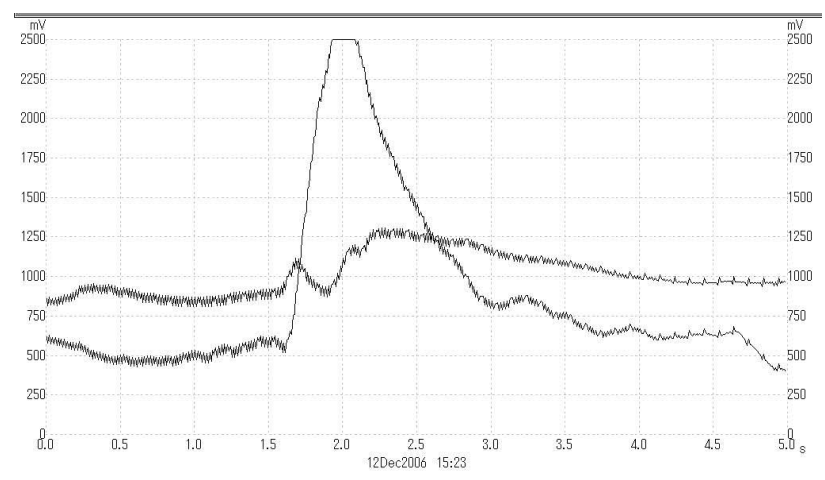

図 8 ストレインゲージでの結果 （腹式呼吸の習得ができている学生）

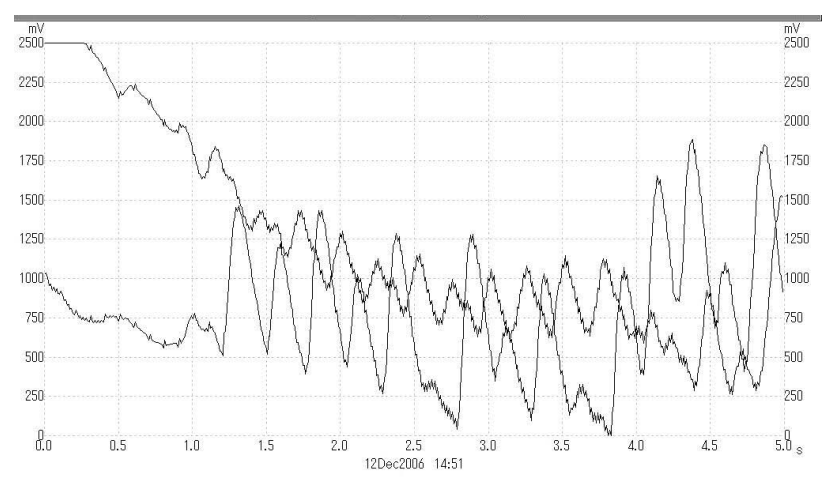

図 9 ストレインゲージでの結果（速いパッセージでの歌唱）

のは，呼気量だけの問題ではなく，声帯振動を起こさ せる声門下圧も重要である。これは，声楽では“支え” といわれているが, これについては，また別の角度か らの呼吸法の研究が必要である.

\section{4. 声楽発声訓練への応用}

実際にストレインゲージを付けて，声楽発声での呼 吸を観察した。ゲージは 2 本で，上は上胸部，下は上 


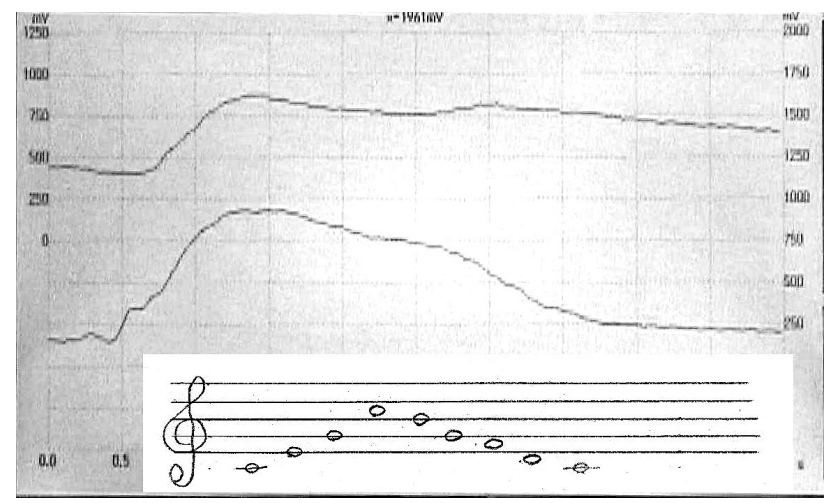

図 10 ストレインゲージでの結果 (ゆっくりとした発声練習)

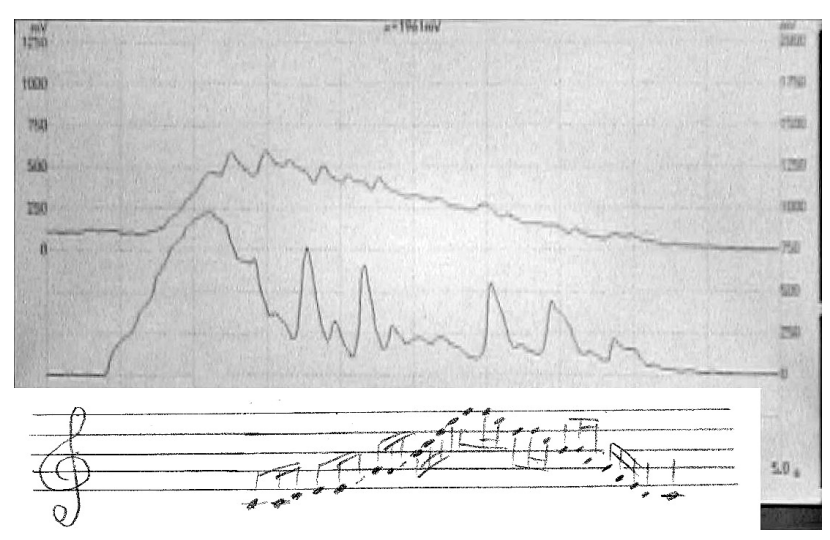

図 11 ストレインゲージでの結果（速い速度での発声練習）

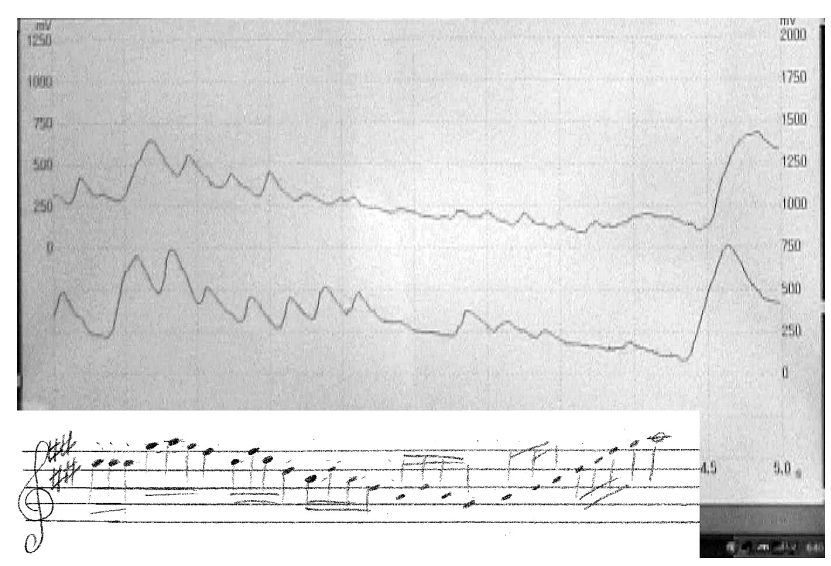

図 12 ストレインゲージでの結果

オペラ「セミラーミデ」のアリア“麗しき光”よりカヴァレッ タの一節.

腹部の位置にゲージを設置した。図 8 は歌曲の 1 フ レーズを歌ったときの息継ぎで，腹式呼吸の習得が比 較的できている学生である。図 9 は速いパッセージを 歌ったときの動きで，上腹部の動きが顕著で，上胸部 にもそれとは異なるタイミングで動きが認められる。 図 10 はゆっくりとした発声練習で, 大きな動きは認

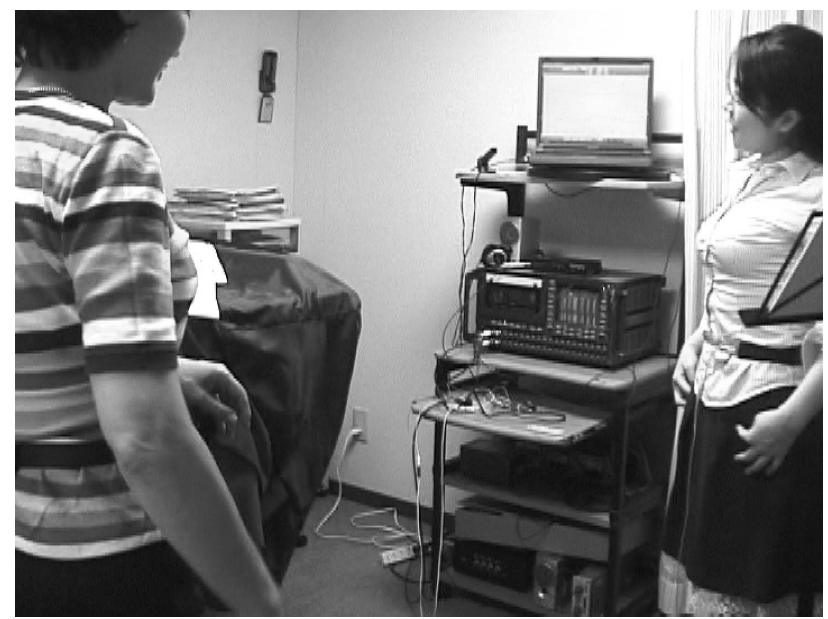

図 13 指導者と学生が 1 組ずつストレインゲージを用いた発 声訓練. 視覚フィードバックによる発声指導が可能.

められない. 図 11 は, 速い速度での発声練習, 図 12 はオペラ「セミラーミデ」のアリア “麗しき光”より カヴァレッタの一節で, 上腹部の動きに遅れて上胸部 にも速い動きが認められる，上腹部の速い動きは，習 得された発声の技術として主に腹筋群で行われ，上胸 部にも影響していると推測するが，この原因について は，さらに検討が必要である。図 10 のように音程が 低くゆっくりとしたフレーズでは，ストレインゲージ の変化幅はあまりなく, 図 9,11，12 のように速いフ レーズでは，変化が大きかった，個人差があり，速い フレーズでも変化が少ない場合もあるが，このような 場合, 声带結節があった症例を経験している。図 13 は, 指導者と学生が 1 組ずつストレインゲージを用いた発 声訓練で, 視覚フィードバックによる発声指導が可能 である。

\section{5. ストレインゲージの実験から推測されたこと}

呼吸は，声带を振動させる呼気を供給することと， 声門下圧を高めることに直接関与している。音程の調 節は, 声带の進展と緊張による喉頭調節と, 声門下圧 により行われている。速いフレーズでは，ストレイン ゲージの結果でわかるように呼気筋の速い収縮によ り, 上腹部周囲の狭小に伴う胸郭と腹腔の狭小化を起 こさせる，上腹部は，背中側に肋骨があり，下胸部の 運動と連動するものと推測されるため, 胸郭全体が速 い間隔で狭小化し元に戻る運動の繰り返しが起きてい ることが推測される。, 一方, 上腹部の狭小化は, 腹 筋群の収縮を意味し, 結果的に腹圧の上昇をもたら し，横隔膜を上方移動させる。すなわち上腹部ストレ インゲージの速い動きは, 胸郭の速い狭小化と横隔膜 の速い上方への移動，それによる声門下圧の速い変動 


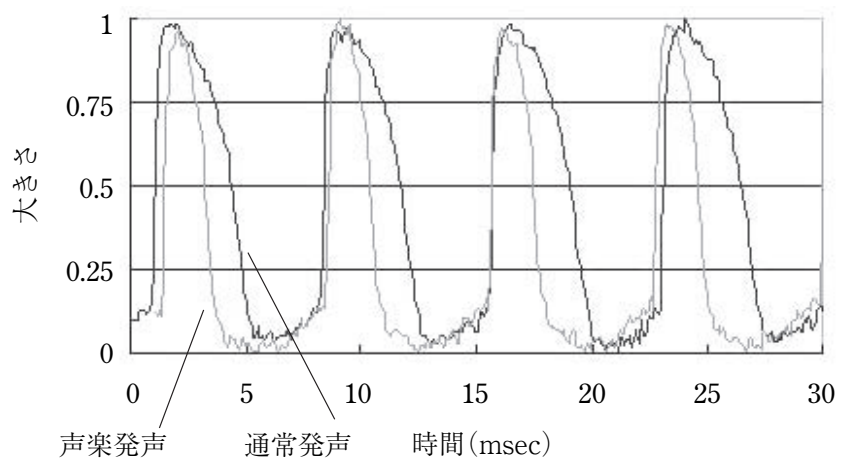

図 14 EGGによる声帯振動の分析（通常発声と声楽発声）

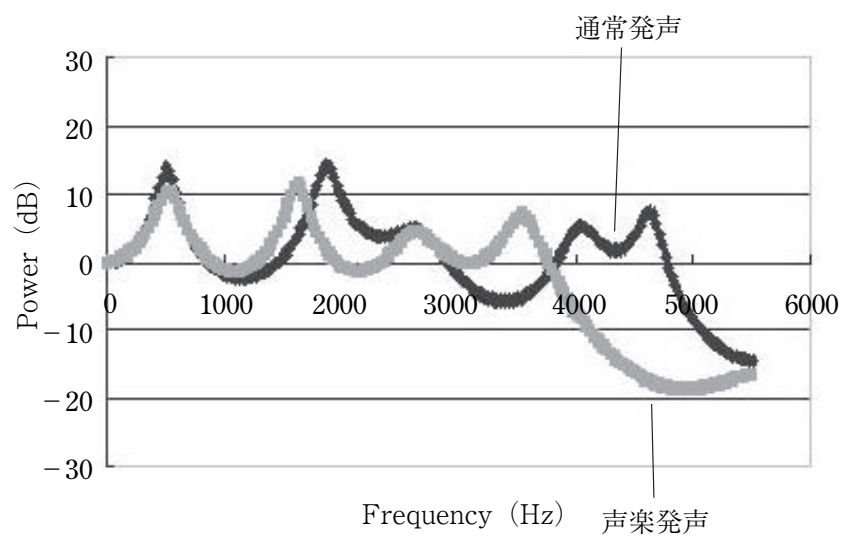

図 15 音響分析による singing formant（通常発声と声楽発声）

が起きることを推測させる，音程を決定する因子の一 つである声門下圧を速く変化させることで，他の音程 を決定する因子である声帯の伸展と声帯の緊張度の変 化の負担を軽減しているのではないかと推測する。ま た音程が低くゆっくりとしたフレーズでは，ストレイ ンゲージの変化幅は少なかった。これは，音程が低く ゆっくりとしたフレーズでは, 声帯の伸展と緊張のみ で音程を決めることが容易で，呼吸では声門下圧を一 定に保つことを優先させているのではないかと推測さ れた。しかし，今回の実験は，私とその関係者のみで あるため, 今後症例を増やし研究したいと考えている.

\section{音響分析と EGG 併用によるストレインゲージを 用いた声楽発声指導}

声は, 呼気, 声帯振動, 共鳴と構音により生成さ れる。発声法を調べるには，これらについて，それ ぞれ調べ統括的に検討するのが望ましい．声带振動 は，ストロボスコープ等を用いた内視鏡検査で可能 であるが，通常の発声訓練には不向きである，EGG （electroglottogram）は，容易に声带の振動状態の情 報を得られる機器で，声帯の接触面積の変化を調べる

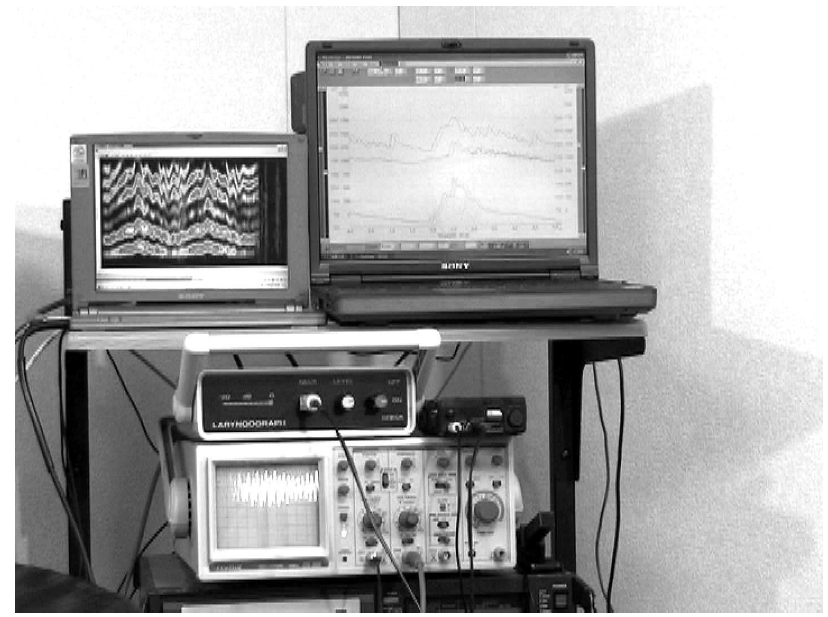

図 16 検査機器

左上：音響分析，右上：ストレインゲージ, 下：EGG

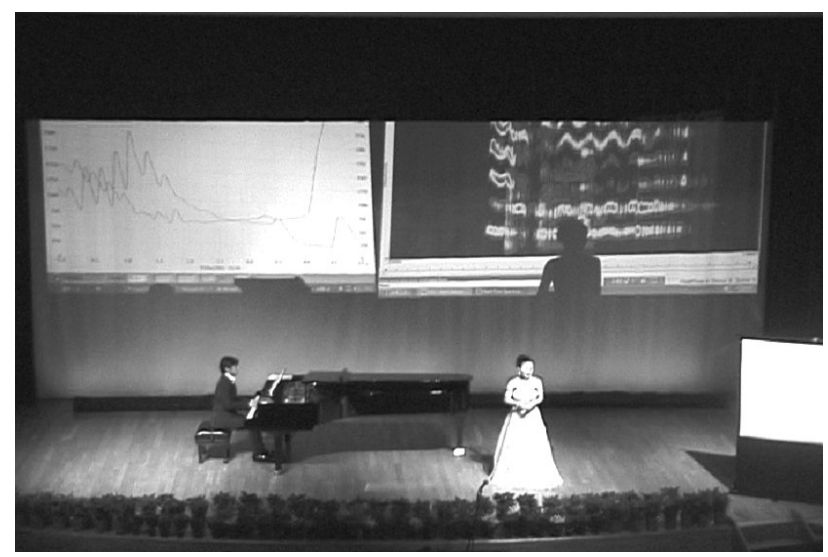

図 17 声の健康の啓蒙活動“あなたの声を良くするレク チャーコンサート”. 左上：ストレインゲージ，右上： 音響分析

ことができるため, 発声時ののどの力の入れ具合を間 接的に調べることが可能である3.4). 図 14 は，通常発 声と声楽発声で, 同じ声の高さ $(136 \mathrm{~Hz})$, 強さで発 声したときの EGGのデータで，声楽発声では，EGG の上向きカーブが鋭くなっている。これは発声時に 声帯接触面積が少なくなったことを意味し，声楽指 導でよく使われる“声帯を薄く使う”ことに匹敵す る。同時にこの音声を音響分析すると，図 15 のよう に, 声楽発声では, ホルマント周波数の移動が見られ, J. Sundberg が提唱する singing formant が認められ, 声楽的な豊かな声と認識される ${ }^{5)}$ 。これらの検査は, リアルタイムに客観的に分析することができるので, ストレインゲージでの呼吸法チェックと併用し声楽発 声指導での応用が可能である。図 16 に検査機器を示 す。またこれらのデー夕は,リアルタイムで表示でき, プロジェクターを使い多人数で観察することも可能 
で，現在，声の健康の啓蒙運動として私たちが行って いる“あなたの声を良くするレクチャーコンサート” で集団での発声訓練の説明で活用している（図 17）. ストレインゲージシステム, EGG，音響分析はリア ルタイムで客観的判断が可能なので，その相互関係を 調べることで, 今後声楽での発声指導や音声障害の原 因究明のための統括的声の分析法として, 発展させて いきたいと考えている.

\section{まと め}

1.ストレインゲージによるリアルタイム呼吸運動 チェックシステムは, 視覚フィードバックにより, 客 観的に呼吸運動を観察できるため, 声楽発声の指導で 有効であった。

2.ストレインゲージリアルタイム呼吸運動チェッ クシステムは, EGGや音響分析などとの併用での相 互関係の精査により，統括的声の分析法として役立つ のではないかと思われた。

謝辞 : 本シンポジウムで発表の機会を与えてくださった第
53 回本学会総会会長, 県立広島大学教授 今泉 敏先生, 司会 の労と御助言をいただきました徳島大学名誉教授 小池靖夫先 生, 国際医療福祉大学教授 新美成二先生に深謝いたします. 本研究は, 大山 玄工学博士の協力を得た.

\section{文献}

1) Saida H: A clinical study of vocal disorders in patients singing classical songs. Ann Bull 26 RILP: 123-132, 1992.

2）斉田晴仁：音声治療を実施する耳鼻咽㑨科開業医の立場か らーLED ストロボスコピーとストレインゲージを用いた 呼吸運動の分析等一。音声言語医学, 50 ：144-152, 2009.

3）斉田正子：19 世紀イタリアベルカントオペラの歌唱につ いて, 狂乱の場を中心として。東京藝術大学紀要，18： 73-98, 1993.

4）斉田晴仁, 今泉 敏, 廣瀬 肇, 他：歌声声区変換機構の 空気力学的, 音響学的検討. 喉頭, 6:24-32, 1994.

5) Sundberg J: The Science of the Singing Voice. Northern Illinois University Press, pp 115-124, 1987.

別刷請求先： $=176-8525$ 東京都練馬区旭丘 2-42-1 日本大学芸術学部音楽科 斉田正子 